C0575-dental-transition-to-recovery-SOP-4June.pdf (accessed June 2020)

17. Scottish Dental Clinical Effectiveness Programme. Management of Acute Dental Problems During COVID19 Pandemic. 2020. Available at http://www.sdcep. org.uk/wp-content/uploads/2020/03/SDCEP-MADPCOVID-19-guide-300320.pdf (accessed April 2020).

18. British Endodontic Society. Diagnosis and Management of Endodontic Emergencies, a British Endodontic Society Position Paper for Primary Dental Care and other healthcare providers during the COVID-19 pandemic. 2020. Available at https://britishendodonticsociety. org.uk/wp-content/uploads/2020/04/BES-EmergencyProtocol-v3-April-23-1.pdf (accessed May 2020).

19. Public Health England. COVID-19: personal protective equipment use for aerosol generating procedures. 2020. Available online at https://www.gov.uk/ government/publications/covid-19-personalprotective-equipment-use-for-aerosol-generatingprocedures (accessed May 2020).

20. Bennett A M, Fulford M R, Walker J T, Bradshaw D J, Martin M V, Marsh P D. Microbial aerosols in general dental practice. Br Dent J 2000; 189: 664-667.

21. Public Health England. COVID-19: infection prevention and control guidance. 2020. Available at https:// assets.publishing.service.gov.uk/government/uploads/ system/uploads/attachment data/file/893320/COVID19_Infection_prevention_and_control_guidance_ complete.pdf (accessed May 2020).

22. Faculty of General Dental Practice (UK) and College of General Dentistry. Implications of COVID-19 for the safe management of general dental practice: A practical guide. 2020. Available at https://www.fgdp.org.uk/ sites/fgdp.org.uk/files/editors/Implications\%20of\%20 COVID-19\%20for $\% 20$ the $\% 20$ safe $\% 20$ management $\% 20$ of $\% 20$ general $\% 20$ dental $\% 20$ practice $\%$ C $2 \%$ A0- $\% 20$ \%20practical\%20guide.pdf (accessed June 2020).

23. Rees J. Asepsis in implant dentistry. Prim Dent J 2012; 1: 47-49.
24. Kampf G, Todt D, Pfaender S, Steinmann E. Persistence of coronaviruses on inanimate surfaces and its inactivation with biocidal agents.J Hosp Infect 2020; 104: 246-251.

25. Eggers M, Koburger-Janssen T, Eickmann M, Zorn J. In vitro bactericidal and virucidal efficacy of Povidonelodine gargle/mouthwash against respiratory and oral tract pathogens. Infect Dis Ther 2018; 7: 249-259.

26. Kawana R, Kitamura T, Nakagomi 0 et al. Inactivation of human viruses by povidone-iodine in comparison with other antiseptics. Dermatology 1997; DOI: 10.1159/000246027.

27. Farzan A, Firoozi P. Common Mouthwashes for PreProcedural Rinsing in Dental Practice: Which One Is Appropriate For Eliminating Coronaviruses? A Mini Literature Review. J Regener Reconstr Restor 2020; DOI: 10.22037/rrr.v5i1.29543.

28. Kirk-Bayley J, Challacombe S, Sunkaraneni S, Combes J. The Use of Povidone lodine Nasal Spray and Mouthwash During the Current COVID-19 Pandemic May Protect Healthcare Workers and Reduce Cross Infection. 2020. Available online at https://papers.ssrn.com/sol3/papers. cfm?abstract_id=3563092 (accessed March 2020).

29. Cochran M A, Miller C H, Sheldrake M A. The efficacy of the rubber dam as a barrier to the spread of microorganisms during dental treatment. J Am Dent Assoc 1989; 119: 141-144.

30. Samaranayake L P, Reid J, Evans D. The efficacy of rubber dam isolation in reducing atmospheric bacterial contamination. ASDC J Dent Child 1989; 56: 442-444.

31. Byström $A$, Sundqvist $G$. Bacteriologic evaluation of the efficacy of mechanical root canal instrumentation in endodontic therapy. Scand J Dent Res 1981; 89: 321-328.

32. Harrel S K, Barnes J B, Rivera-Hidalgo F. Reduction of aerosols produced by ultrasonic sealers. J Periodonto 1996; 67: 28-32.

33. Jacks M E. A laboratory comparison of evacuation devices on aerosol reduction. J Dent Hyg 2002; 76: 202-206.
34. Hand R E, Smith M L, Harrison J W. Analysis of the effect of dilution on the necrotic tissue dissolution property of sodium hypochlorite. J Endod 1978; 4: 60-64.

35. Stojicic S, Zivkovic S, Qian W, Zhang H, Haapasalo M. Tissue dissolution by sodium hypochlorite: effect of concentration, temperature, agitation, and surfactant. J Endod 2010: 36: 1558-1562.

36. Hülsmann M, Peters O A, Dummer P M. Mechanical preparation of root canals: shaping goals, techniques and means. Endod Topics 2005; DOI: 10.1111/j.1601-1546.2005.00152.x.

37. Siqueira Jr J F, Rôças I N. Clinical implications and microbiology of bacterial persistence after treatment procedures. J Endod 2008; 34: 1291-1301.

38. British Endodontic Society. BES COVID-19: Return to Work SOP. 2020. Available at https://britishendodonticsociety. org.uk/wp-content/uploads/2020/06/BES_SOP080620-v1.pdf (accessed June 2020).

39. Ng Y L, Mann V, Rahbaran S, Lewsey J, Gulabivala K. Outcome of primary root canal treatment: systematic review of the literature - Part 2. Influence of clinical factors. Int Endod J 2008; 41: 6-31.

40. Dental Trauma UK and British Society of Paediatric Dentistry. Permanent Dentition Acute Management of Traumatic Injuries and Follow-up Care during the COVID-19 Pandemic. 2020. Available at https://www. dentaltrauma.co.uk/File. ashx?id=15336 (accessed June 2020)

41. National Institute for Health and Care Excellence. Antimicrobial stewardship: systems and processes for effective antimicrobial medicine use. 2015. Available at https://www.nice.org.uk/guidance/NG15/chapter/1Recommendations\#recommendations-for-prescribers (accessed April 2020).

42. Alani A, Bishop K. Contemporary issues in the provision of restorative dentistry. Br Dent J 2012; 213: 163-170.

43. Ng Y-L, Mann V, Gulabivala K. Outcome of secondary root canal treatment: a systematic review of the literature. Int Endod J 2008; 41: 1026-1046.

\section{Correction to: The changing face of dental practice: emerging models of team care in Australia}

The original article can be found online at https://doi.org/10.1038/s41415-020-1529-3.

\section{Author's correction note:}

Research article Br Dent J 2020; 228: 767-772.

When this article was published there were errors in Figures 1 and 2.

The correct version of Figures 1 and 2 are presented here:

The original article has been corrected.

\section{Fig. 1 Child models of care}

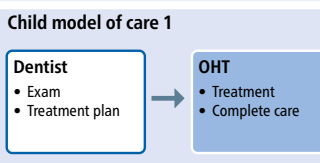

Child model of care 2

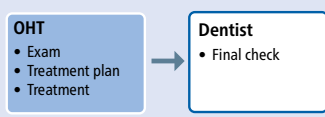
Child model of care 3

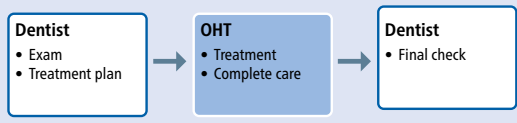

Child model of care 4

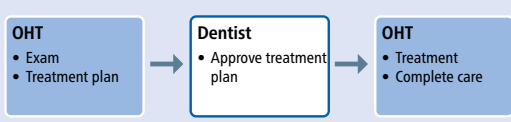

Child model of care 5 OHT - Exam - Exam
- Treatment plan
- Treatment - Complete care ete car

\section{Fig. 2 Adult models of care}

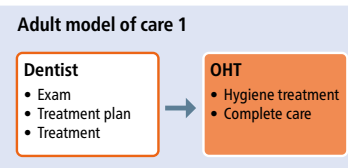

Adult model of care 2

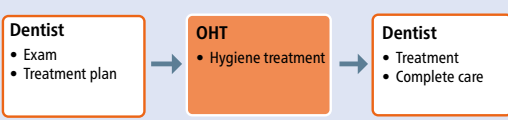

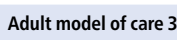

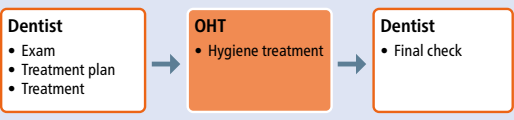

Adult model of care 4
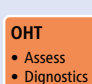
- Assess - Hygiene treatm

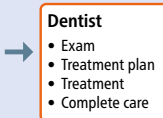

